Ethiopian Journal of Environmental Studies \& Management 8(Suppl. 2): 949 - 965, 2015.

ISSN:1998-0507

doi: http://dx.doi.org/10.4314/ejesm.v8i2.9S

Submitted: July 31, 2015

Accepted: November 13, 2015

\title{
RETRIEVAL OF AEROSOL OPTICAL DEPTH OVER ECOLOGICALLY STRESSED EAST AFRICAN LAND SURFACES FROM TOP OF ATMOSPHERE RADIANCE UTILIZING THE AEROSOL FREE VEGETATION INDEX
}

\author{
${ }^{*}$ MAKOKHA, J.W., ${ }^{1,2}$ ANGEYO, H.K. ${ }^{1}$ AND MUTHAMA, J.N. ${ }^{3}$ \\ ${ }^{1}$ Department of Physics, University of Nairobi, P.O. Box 30197-00100, Nairobi, Kenya \\ ${ }^{2}$ Department of Physical Sciences, University of Kabianga, P.O. Box 2030-20200, Kericho, \\ Kenya \\ ${ }^{3}$ Department of Meteorology, University of Nairobi, P.O. Box 30197-00100, Nairobi, Kenya
}

\begin{abstract}
Traditional satellite based $A O D$ retrieval techniques with a coarse resolution such as collection 5 hardly provides a high spatial detail suitable for accurate AOD retrieval particularly over the ecologically stressed sites of East Africa. Furthermore, AOD retrievals from Moderate Resolution Imaging Spectroradiometer (MODIS-collection 5) require a linear mixing model that utilizes the normalized difference vegetation index (NDVI) to calculate surface reflectance. Since NDVI is affected by the presence of aerosols in the atmosphere, an empirical linear relationship between short wave infrared (SWIR) and visible reflectance were estimated in order to calculate a modified aerosol free vegetation index (AFRI). Based on $A F R I$ and the minimum reflectance technique (MRT), an improved linear mixing model was developed. Calculated Vis/SWIR ratio diverges from the one used in the hypothetical model for $A O D$ retrieval. Likewise, the regression coefficients between retrieved $A O D$ for the developed algorithm and AERONET were higher as compared to that of MODIS collection 5 and AERONET. These emphasize the need of using AFRI plus accurate selection of surface characteristics and aerosol type for accurate $A O D$ retrieval over East Africa that is addressed by the developed algorithm. At low AERONET AOD values, the two algorithms i.e. MODIS and developed agree but as the AERONET AOD value increases, a discrepancy is noted between the two as a result of usingNDVI and AFRlin the MODIS and developed algorithms respectively.
\end{abstract}

Key Words: Atmospheric aerosol, Optical depth, Remote sensing, Reflectance, East Africa

\section{Introduction}

Atmospheric aerosols are the most abundant and variable component of the Earth's atmosphere (IPCC, 2007). The main types of aerosol over Africa are desert dust and biomass burning aerosols which are UV-absorbing. In particular, Western Sahara is a major source for dust (Prospero et al., 2002; Reid et al., 2003;
Kaufman et al., 2005) that is normally transported to the tropical North-Atlantic Ocean and the Mediterranean Sea yearly (D'Almeida, 1986; Prospero et al., 1996; Engelstaedter et al., 2006).This makesthe continent an appropriate place to study aerosol impact on both local and global climate.As well, during the local dry period, smoke and other biomass burning

*Corresponding author: Makokha, J.W.

Email: makokhajw@gmail.com 
aerosols areproduced by annually recurring Savanna fires in all vegetated parts of Africa. These aerosols are known to be chemically active with their internal physico-chemical properties changing rapidly in a few hours to days after their release (Reid et al., 2005).

De Graaf et al. (2010) established that Absorbing Aerosol Index (AAI) and residues data are related to monthly mean precipitation data and they show Monsoon controlled aerosol loadings. Seasonal variation in the aerosol distribution was clearly linked to the seasonal cycle of the Monsoonal wet and dry periods over East and West Africa. The residue varies freely due to aerosol emissions from deserts and biomass burning events during dry period while on contrary; they depend linearly on the amount of precipitation as a result of scavenging of aerosols and prevention of aerosol emissions from the wet surface during wet period. This is most clear over East Africa, where the sources and sinks of atmospheric aerosols are controlled directly by the local climate, i.e. Monsoonal precipitation.

Understanding the influence of aerosols on climate howeverrequires identification of aerosol properties i.e. sources, size, sinks and type which can be retrieved from ground-based instruments (AErosol RObotic NETwork (AERONET) (Holben et al., 1998) and Multi-axis Differential Optical Absorption Spectroscopy (MAX-DOAS) (Wittrock $e t$ al., 2004). Alternatively, these properties may also be derived from satellite-based spectroscopic sensorslike theModerate Resolution Imaging Spectrometer (MODIS) (Salomonson et al., 1989). In general, satellite-borne aerosol observations have an advantage over ground-based measurements since they have a large spatial coverage even though only taking one or two observations in a given day and position.
Aerosol properties retrieval over ocean surfacesfrom satellite-based measurements utilizes the Near Infra-Red (NIR) channels (Von Hoyningen-Huene et al., 2003). This is because the ocean surfaces experiences relatively low spectral surface reflectance which can be ignored in the process of aerosol retrieval (Geogdzhayev et al., 2002). Conversely, retrieval of aerosol properties over land is complex, requiring several model assumptions (Torres et al., 1998; 2002). The procedure for a nadir retrieval of AOD for instance fails in NIR due to high surface reflectance and its variability over bright surfaces. However, in the visible regime i.e. $0.4 \mu \mathrm{m}<\lambda<0.67$ $\mu \mathrm{m}$ (with the exception of snow and desert ground) the spectral surface reflectance has values in the range $\leq 0.05$ that decrease with decreasing wavelength. Therefore, retrieval of aerosol properties over land requires separation techniques to consider the variable contribution of surface reflectance.

Kaufman and Tanre (1998) proposed the dense dark vegetation (DDV) method using the multiband algorithm from MODIS satellite images (collection 4). It was later noted that this technique works efficiently over vegetation areas characterized by low surface reflectance but for bright surfaces such as deserts, coastal, arid and urban areas (main sources of anthropogenic aerosols), it fails. This is because the DDV method makes assumption that the vegetation is sufficiently dark and the ratio between the bottom of atmosphere (BOA) and top of atmosphere (TOA) reflectance at different wavelengths is constant (Gillingham et al., 2012). Additionally, Chu et al. (2002) showed that the MODIS collection 4 algorithm has a positive bias when compared to data retrieved from the AERONET sunphotometer while Levy et al. (2004) and Remer et al. (2005) reported 
some inherent problems in using the DDV algorithm.

The contribution of surface reflectance on AOD retrieval is well documented (Von Hoyningen-Huene et al., 2003; Lee et al., 2006; Guo et al., 2009; Wong et al., 2010). Any attempt to retrieve aerosol characteristics from a satellite image depends on the method of decoupling both surface and aerosol reflectance and its subsequent modeling using a radiative transfer model (RTM). Levy et al. (2007) modified the surface reflectance determination in the MODIS aerosol retrieval algorithm (known as collection 5) by considering NDVI for dark pixel screening, as well as the scattering angle. It was later discovered that NDVI over estimates the surface reflectance and consequently underestimating aerosol reflectance of a given pixel if there is a strong aerosol influence in the presence of satellite scene. Since retrieval of aerosol reflectance over bright surfaces is a challenge due to the complexity in decoupling both surface and aerosol reflectance, Hsu et al. (2004; 2006) developed a deep blue algorithm for aerosol retrieval over bright surfaces using MODIS imagesmakes use of the blue wavelengths where the surface reflectances are bright in the red region and darker in the blue region.

The region's vegetation cover, aerosols sources and sinks affect the decoupling process of both surface and aerosol reflectance. In order to retrieve and map AOD distributions over theregion with an improved accuracy, a newMODIS (500m) AOD retrieval algorithm was developed. This algorithm utilizes the modified MRT technique and AFRI to decouple surface and aerosol reflectances. This is because AFRI is known to assess the vegetation index in the presence of smoke, anthropogenic natural aerosol sources that dominate the region.
Rapid urbanization (Nairobi), monsoonal influence (Malindi), biomass burning and land cover change (Mbita) and deforestation (around Mount Kilimanjaro) in the last 30 years necessitates the need to retrieve and improve on the understanding of aerosol contribution on the climate change (Höller et al., 2005) in the region. This understanding should be with appreciable accuracy and confidence since aerosol properties are highly variable. This paper presents results of a newly developed algorithm that utilizes MODIS radiance measurements with AFRI and MRT for AOD retrieval over the ecologically stressed regions of East Africa.

\section{Area of Study}

The study was undertaken over selected AERONET sites in the two East African countries i.e. Kenya and Tanzania so that results from satellite measurements can more easily be ground-referenced shown in Figure 1. Additionally, the selection was also based on physical features known to profoundly modify aerosol characteristics in the immediate atmosphere.

\section{Nairobi}

Nairobi is a fast expanding metropolis in East African region with a tropical high altitude $(1798 \mathrm{~m})$ and is situated at $1^{\circ} \mathrm{S}$, $36^{\circ} \mathrm{E}$. The city is strongly impacted on by local urban pollution attributable to its high populace (about 3.1 million), industrial activities, and smoke aerosols from refuse burning, transport of air masses from biomass burning regions adjacent to it and vehicular emissions characterized by early morning and late evening rush hour.

\section{Mbita}

Mbita is a rural site in South Western Kenya, on the shores of Lake Victoria situated at $0^{\circ} \mathrm{S}, 34^{\circ} \mathrm{E}$ with an altitude of 1125 mand a population of 46,223 . Other than farming, fishing, biomass burning and farm clearance for cultivation activities 
that dominate the site, the region also experiences the Lake-terrestrial air mass exchange due to its nearness to Lake Victoria.

\section{Malindi}

Malindi is a town located at $2^{\circ} \mathrm{S}$, $40^{\circ}$ Ewith an altitude of $12 \mathrm{~m}$, lying on the Indian Ocean coast of Kenya. It is 120 kilometers northeast of Mombasa City with a population of 1.1 million. The site is dominated by maritime conditions associated with sea salt and sea spray aerosols that are known to dominate the $\lambda$ $=0.44 \mu \mathrm{m}$ atmospheric window. Unique to the site is the significance of long distance transport of coarse aerosols from the Arabian Peninsula desert via Monsoon winds (Makokha and Angeyo, 2013).

\section{Mount Kilimanjaro}

Mount Kilimanjaro, located at $3^{\circ} \mathrm{S}$, $37^{\circ} \mathrm{E}$, is the highest mountain in Africa, and the highest free-standing mountain in the world at 5895 metres above sea level with an area of approximately $75 \mathrm{~km} \times 75$ $\mathrm{km}$. The disappearance of the mountain's glaciers is associated to deforestation activities going on around it in the adjacent Kilimanjaro National Park (Fairman et al., 2011).

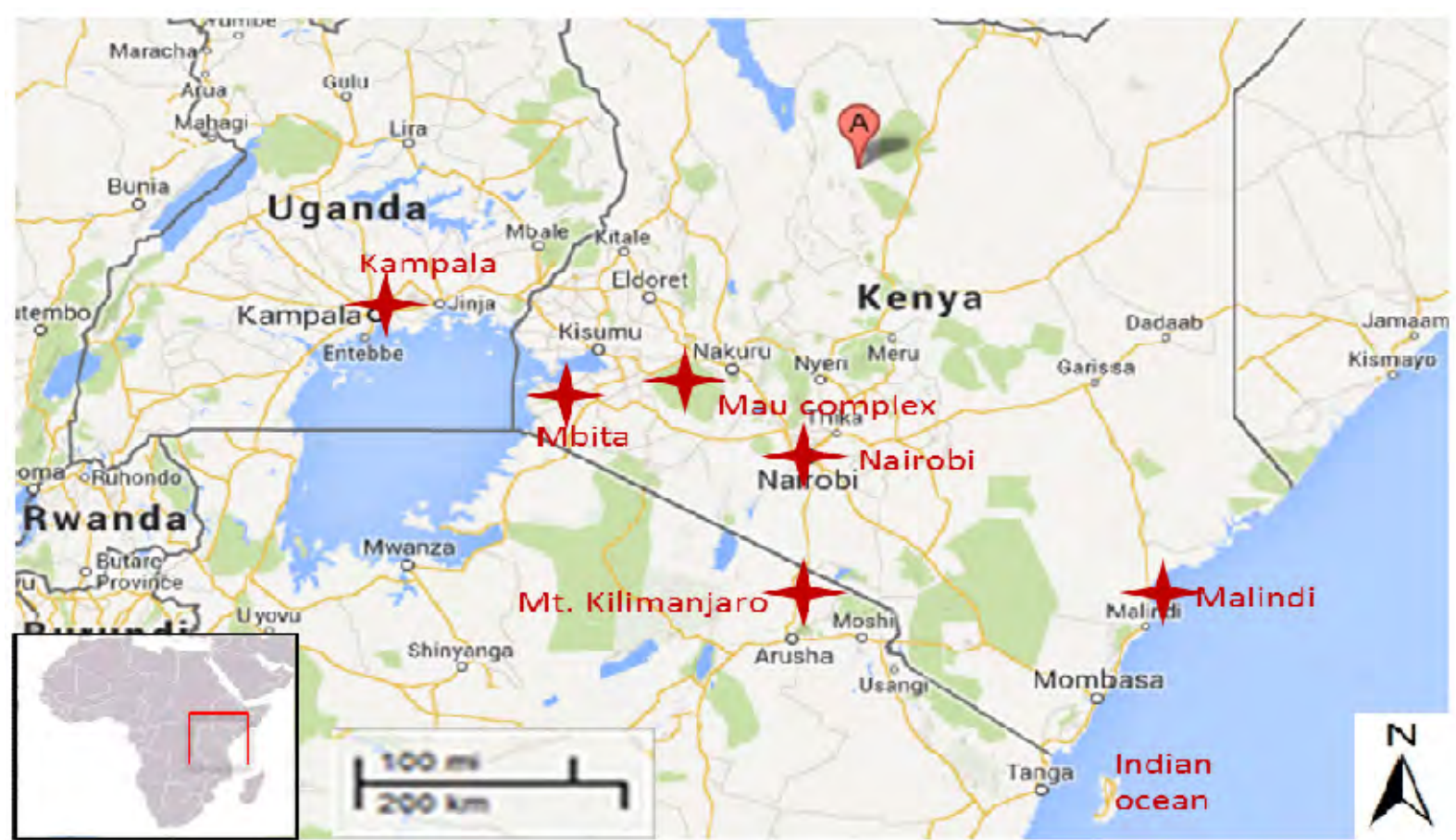

Figure 1: Map indicating the selected sites of study in the East African region.

\section{Materials and Methods Spectral Imaging}

Acquisition of data from satellite imaging sensor utilizes various techniques among them is the push-broom imaging technique (Shaw and Burke, 2003). In this spectral imaging format, the cross trackline of spatial pixels are decomposed into three spectral bands via diffraction grating and wedge filter mechanisms (Seery et al.,
1996). On the other hand, Principal Component Analysis (PCA) was utilized in reduction ofdata dimensionality while preserving essential information in the spectral data cube (Hsu and Burke, 2003). For MODIS L1B data pre-processing procedures i.e. georeferencing, bow tie correction (overlap effect of consecutive scans) and subset (images created for a specific area of the globe) were achieved 
via MODIS TOOL in ENVI 4.0 over each pixel on the ground. Details of various equations used to derive reflectances from MODIS L1B data are discussed elsewhere (Kaufman et al., 1997; Von HoyningenHuene et al., 2007).

\section{Cloud Masking Procedure}

Aerosol properties retrievals depend on accurate cloud masking algorithms that utilizes a combination of different wavelengths (Ackerman et al., 1998). In the present case, the absence of the high resolution thermal band in the MOD02Hkm (500m) data necessitated the development of a tailor-made cloud

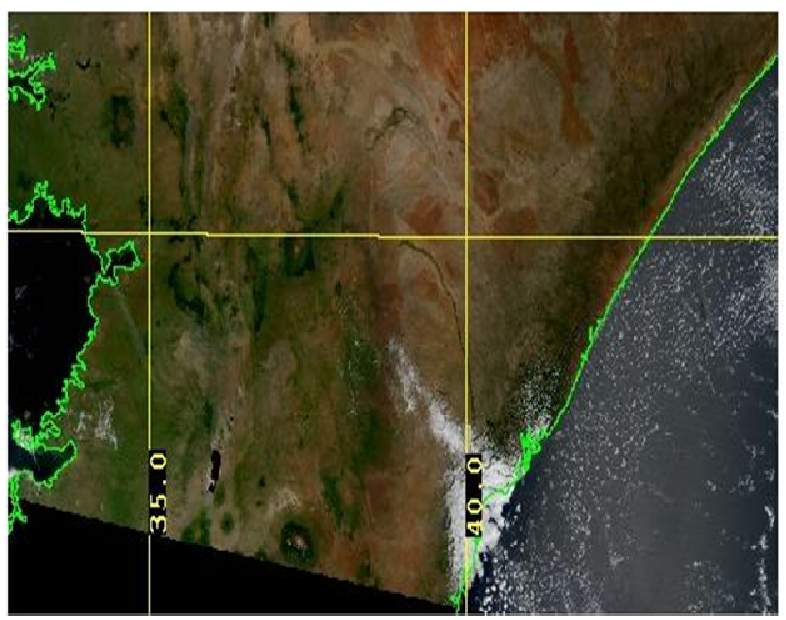

(a) masking algorithm. This masking algorithm reflectance threshold at $550 \mathrm{~nm}$ was based on clear sky conditions on $30^{\text {th }}$ January 2003who'sRGB and gray scale images are shown in Figure 2 for MODIS Terra. The thresholds for aerosol retrieval in each pixel for the channels of interest were set i.e. reflectances $>0.2$ or AFRI<0.5 were all masked for each pixel over the specifiedstudy sites.Additionally, the minimum reflectance technique (MRT) which involves a procedure to find the clearest pixels (i.e. with the lowest reflectance) daily for the period of study was applied.

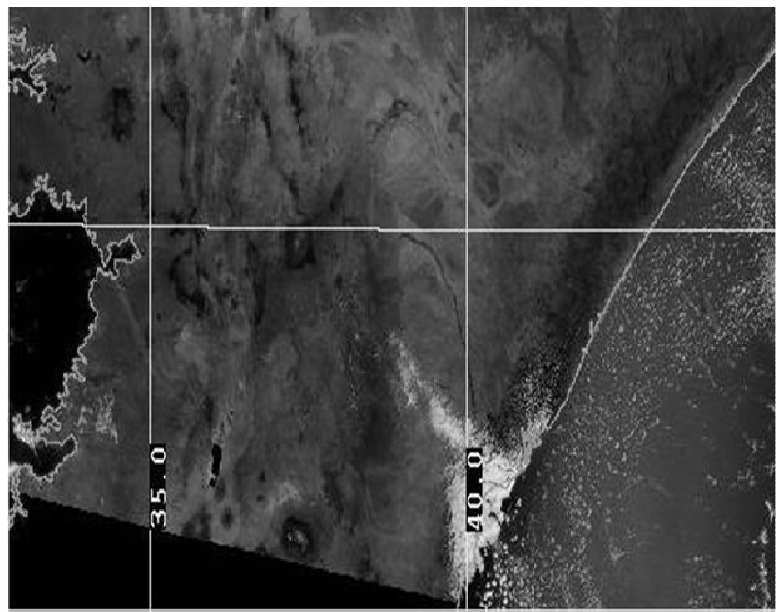

(b)

Figure 2: Clear sky RGB (a) and grey scale (b) images from MODIS Terra over the study sites

Decoupling of Modified Reflectance from TOA reflectance

\section{Rayleigh Path Reflectance}

The modified reflectance $\left(\rho_{M o d}(\lambda)\right)$ is obtained by subtracting the Rayleigh path reflectance from the TOA reflectance for each illumination and observation geometry. Based on digital elevation model (DEM) in the MOD03 geolocation data, height and pressure of each pixel was determined following Wong et al. (2010).Furthermore, determination of
Rayleigh path reflectance was based on its dependence on Rayleigh optical depth (ROD) and phase function as described in both Bucholtz (1995) and Wong et al. (2010).

\section{Surface Reflectance}

Kaufman et al. (1997) shows the process of decoupling $\rho_{\text {Mod }}(\lambda)$. Based on this procedure, a linear relationship between short wave infrared (SWIR) and visible channel reflectance was calculated (Table 1). Thisrelation depends highly on 
land cover type and temporal variation in vegetation index as indicated by Karnieli et al. (2001), hence the need to establish that which fits each study siteis of necessity. AFRI was adopted according to equation 1 with the constant $(C)$ depending on the linear relationship between SWIR and Vis reflectance over each study site to aid in cloud masking as detailed in Table 1.

$$
A F R I_{2.1}=\frac{\rho_{0.55}-C \rho_{2.1}}{\rho_{0.55}+C \rho_{2.1}}
$$

\section{Satellite Signal in the Solar Spectrum (6S) radiative transfer model}

The $6 \mathrm{~S}$ radiative transfer model permits calculations of near-nadir aircraft observations, accounting for target elevation, non lambertian/anisotropic surface conditions, and new absorbing species in the atmosphere. The $6 \mathrm{~S}$ code computational accuracy for Rayleigh and aerosol scattering effects has been improved by the use of state of the art approximations, improved spectral integration to $2.5 \mathrm{~nm}$ and implementation of the successive orderscattering (SOS) algorithm. A detailed description of the methods may be found in Vermote et al. (2006). In this study, the $6 \mathrm{~S}$ code is meant for calculation of look up table (LUT) necessary for AOD retrieval.

\section{Retrieval of Aerosol Reflectance}

TOA reflectance was limited to within \pm 30 minutes of MODIS overpass time AERONET measurement for easy ground referencing. The daily calibrated reflectances were first cloud masked andthen grouped into their respective seasons i.e. those corresponding to dry season (December to February) and Wet season (inclusive of both short and long rains i.e. March to November) (Kaufman et al., 1997). The MRT was used in identifying pixels with TOA reflectance values $\leq 0.2$ after which Rayleigh scattering effects were corrected as discussed in a section on Rayleigh path reflectance. Surface and aerosol reflectances were decoupled using the AFRI as detailed in the surface reflectance section.

The scheme in Figure 3 runs on Ubuntu Linux with a pre-installed Python 2.7.X version. Python modules i.e. Numpy, Scipy, Matplotlib, Python-dateutil, Pysolar and Pandas were downloaded from their respective repositories and installed in the respective order. Py6S, an interface to the 6S atmospheric RTM through the Python programming language was utilized in the retrieval of AOD. 


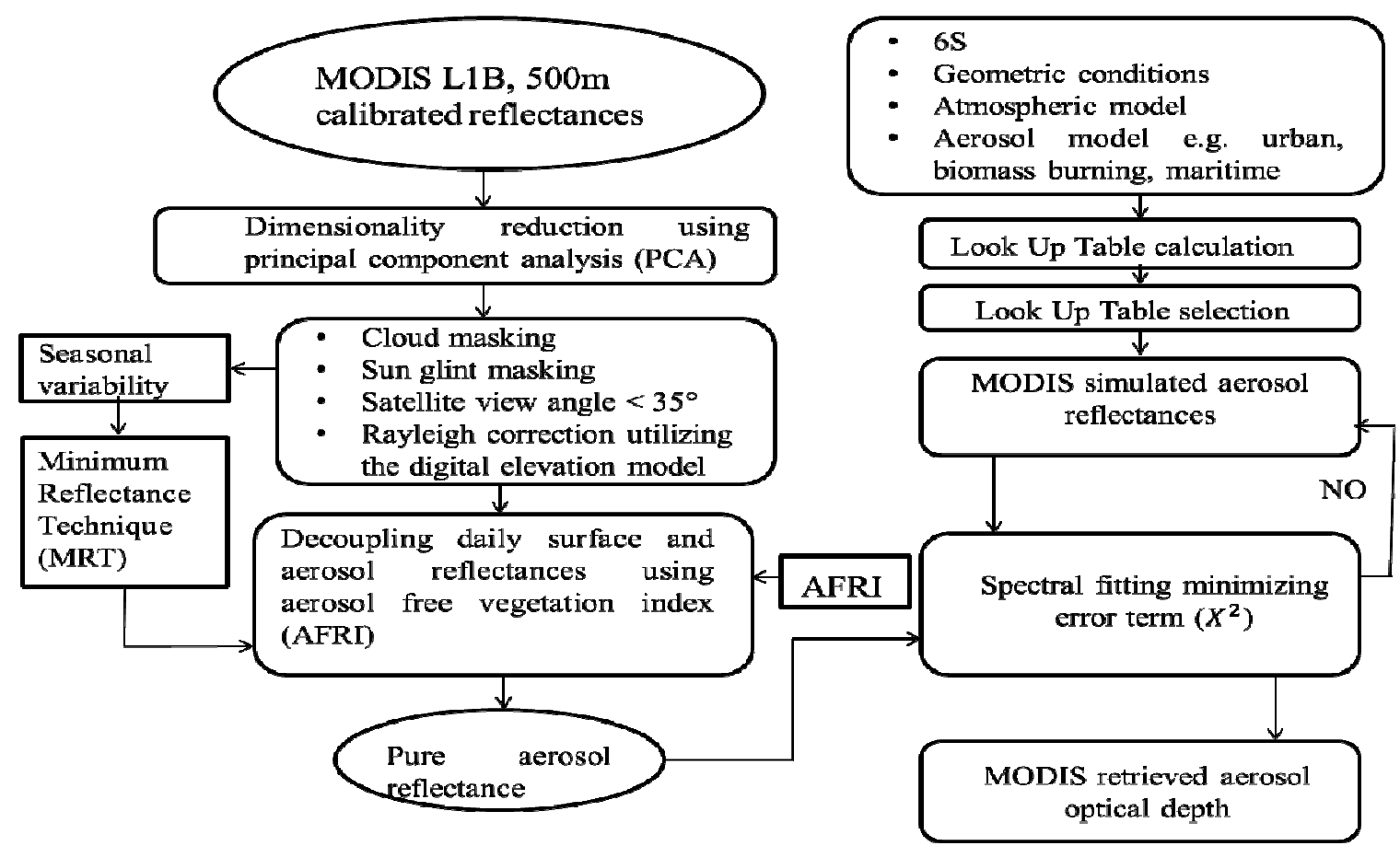

Figure 3: The schematic diagram for the developed aerosol optical depth retrieval algorithm

\section{Retrieval of Aerosol Optical Depth}

Inputs to the $6 \mathrm{~S}$ comprise of geometric conditions (solar zenith angle, solar azimuth angle, sensor zenithal angle and sensor azimuthal angle), atmospherical model (tropical), aerosol models (biomass burning, urban and maritime) and a homogeneous surface were utilized. A comprehensive LUT was constructed using the $6 \mathrm{~S}$ code for calculating aerosol reflectance as a function of AOD under various sun viewing geometries (only nadir images with satellite viewing angle $<35^{\circ}$ ) based onaccurate optimal spectral shape fitting according to Wong et al. (2010). For the purpose of validation, only AOD values at $550 \mathrm{~nm}$ were determined here since MODIS collection 5 end products are only at this wavelength and then compared to AERONET ground measurements.

\section{Results and Discussions}

\section{Relationship between the visible and SWIR bands}

The surface reflectance ratio between the Vis and SWIR radiation is animportant quantity for AOD retrieval from MODIS Terra. Based on empiricallydetermined Vis/SWIR ratios, AOD retrievaluses the surface reflectance in the SWIR band $(2100 \mathrm{~nm})$, where the interaction between solar radiation and the aerosollayer is small, to predict the visible reflectances in the $550 \mathrm{~nm}$ band. Figure 5 shows Vis/SWIR ratios over each study site during dry and wet seasons from February 2000 to December 2013. Basically, other than the criterion set in the algorithm (Figure 3), the choice of MODIS Terra Rayleigh corrected reflectance to be used in the determination of the Vis/SWIR ratios over each study site was limited to:

1. A complete monthly data set is composed of more than $50 \%$ qualified daily reflectances in each of the two spectral bands.

2. The SWIR reflectance was limited to a value less or equal to 0.15 as per the criterion given by MRT.

Thus, based on the stated criterion, Vis/SWIR ratios were plotted as shown in Figure 4 over each study site. 


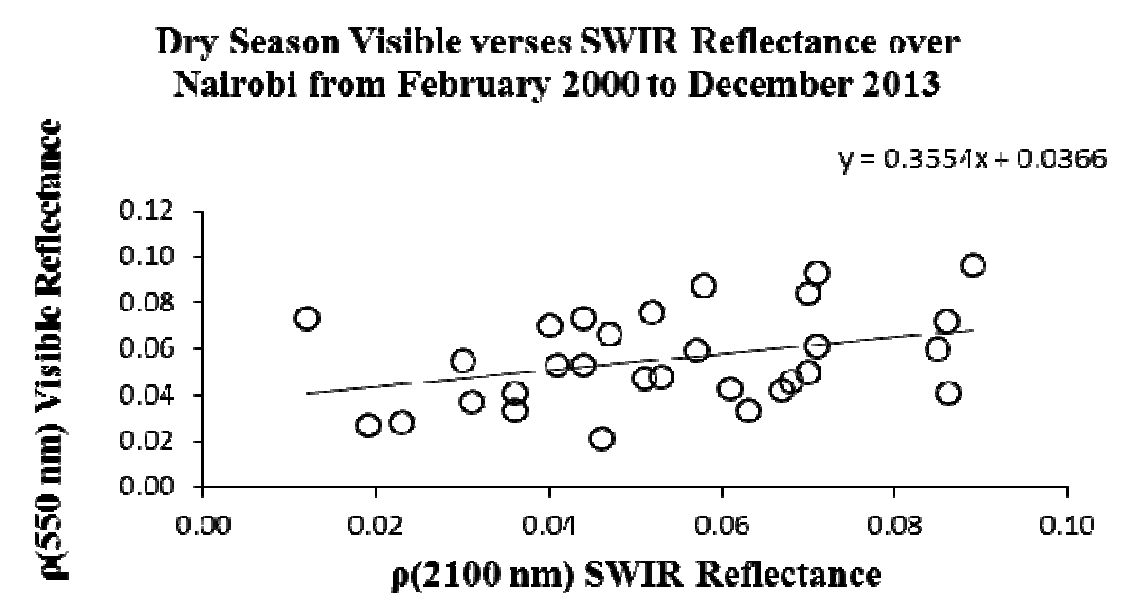

(a)

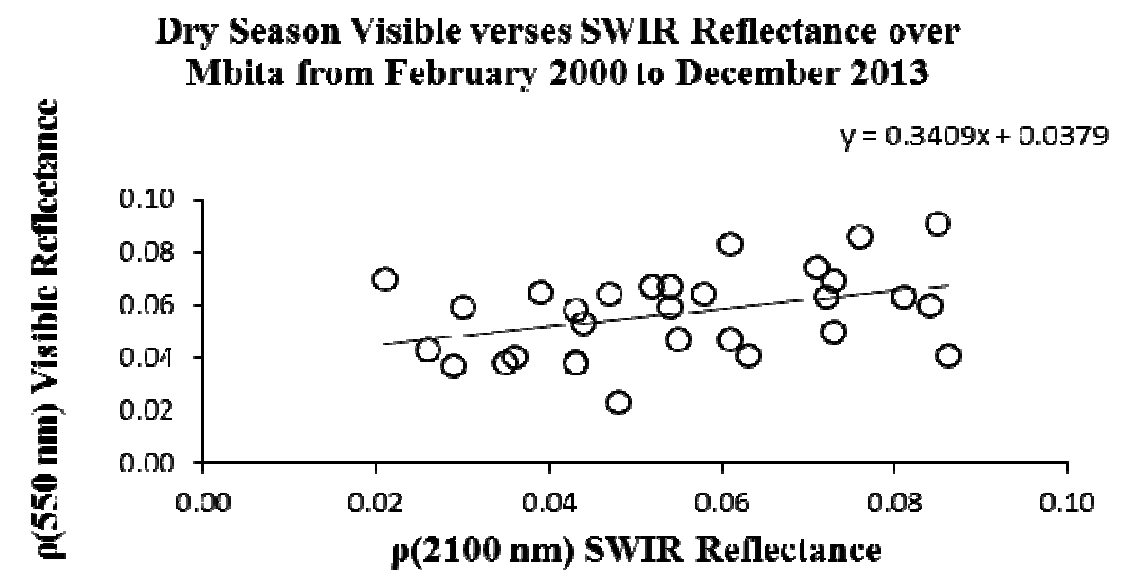

(c)

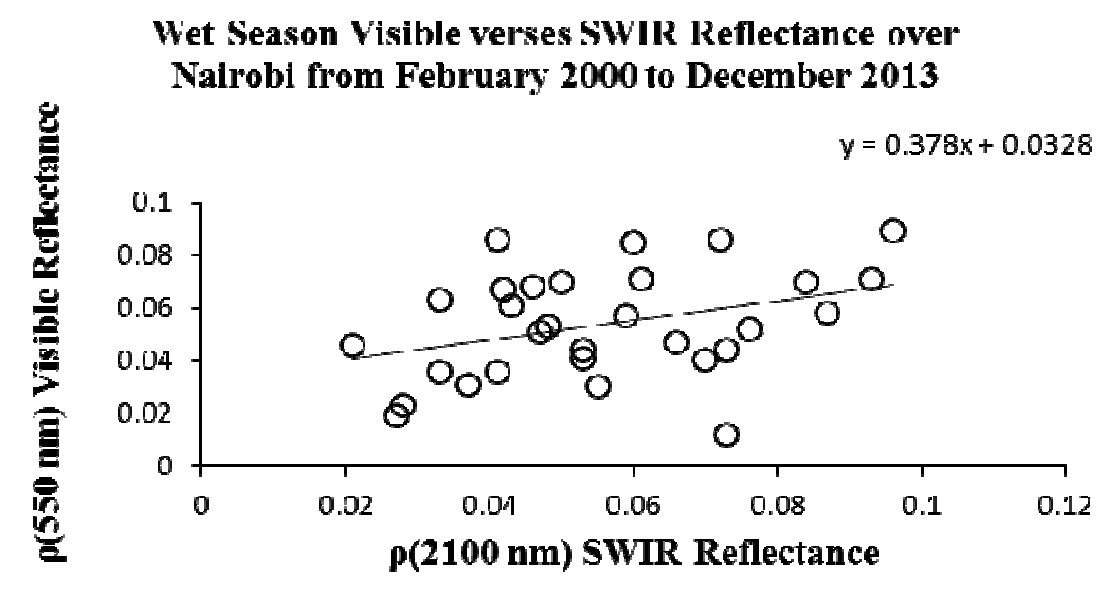

(b)

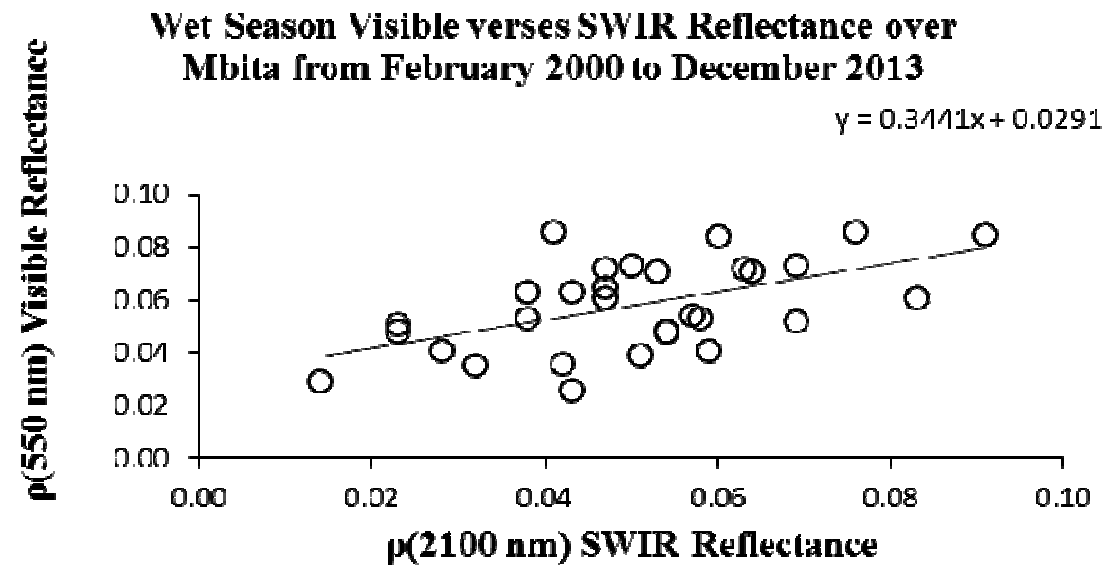

(d) 


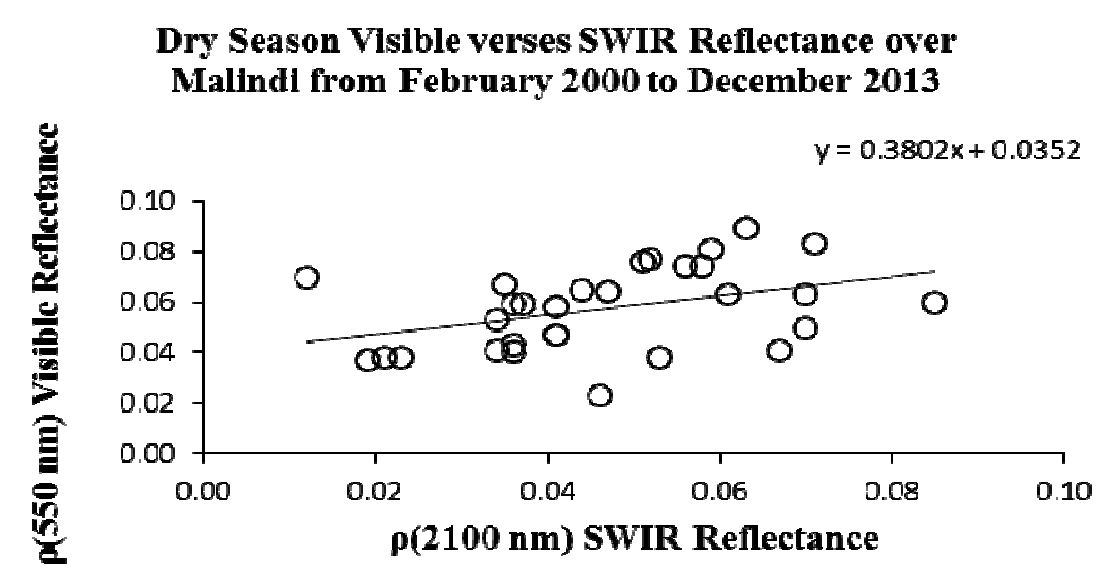

(e)

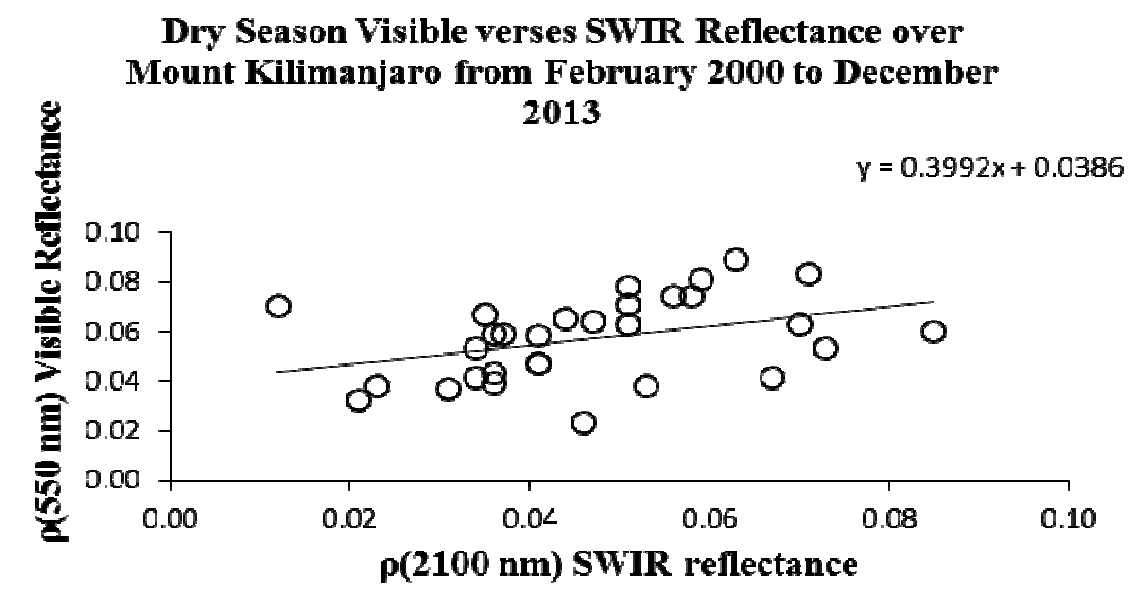

(g)

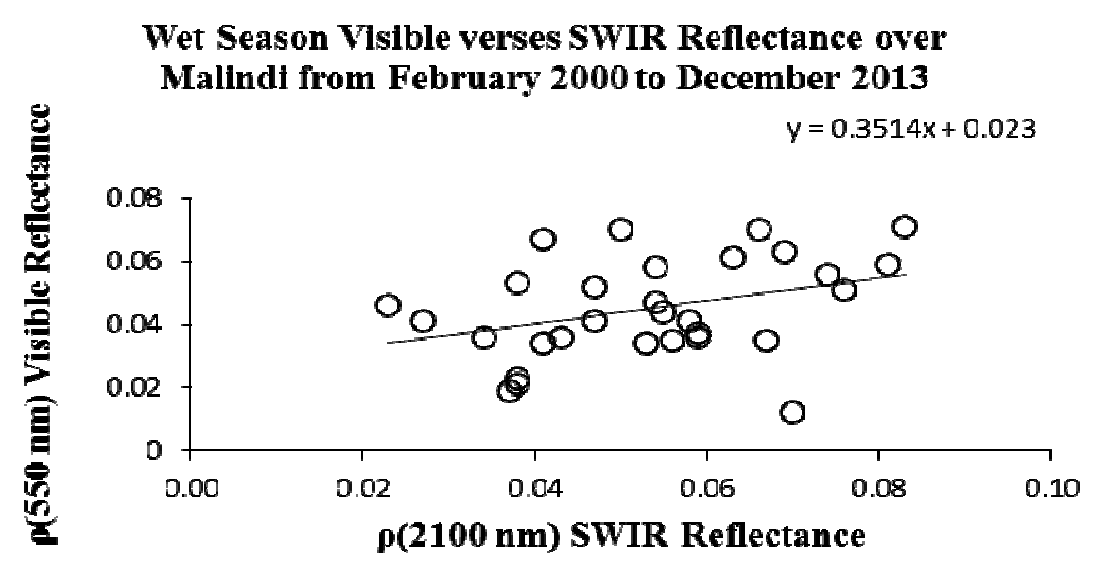

(f)

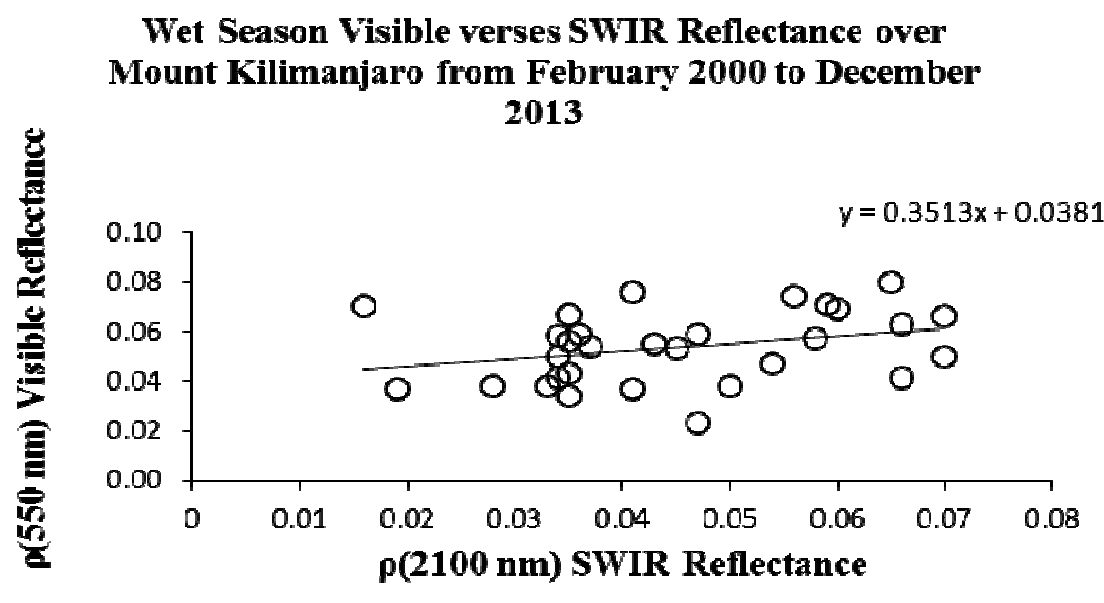

(h)

Figure 4: Relation between the Rayleigh corrected visible $(550 \mathrm{~nm})$ and SWIR spectral bands $(2100 \mathrm{~nm})$ reflectances averaged fordry season (Column 1) and wet season (Column 2) over each study site from February 2000 to December 2013. 
The Vis/SWIR ratio over each study site differs from the one proposed for AOD retrieval in the hypothetical model (Kaufman et al., 1997; Karnieli et al., 2001). The variation is more significant during the dry season as compared to the wet season since this ratio is highly depended on land cover type and temporal variation of vegetation. Figure 4 clearly shows that the use of hypothetical model values proposed by Kaufman et al. (1997) in the retrieval of AOD over the East African atmosphere will be inaccurate. Therefore, the hypothetical model values cannot always be used to calculate surface reflectance for aerosol retrieval over the study sites. The slope and intercept of atmospheric corrected reflectance over each site of study were as shown in the Table 1.

Table 1: The slope and intercept (in bracket) of atmospheric corrected reflectances at $550 \mathrm{~nm}$ verses $2100 \mathrm{~nm}\left(\rho_{2.1} \leq 0.15\right)$ spectral bands from February 2000 to December 2013.

\begin{tabular}{llll}
\hline Site of Study & Dry Season & Wet Season & $\begin{array}{l}\text { Hypothetical model proposed by } \\
\text { Kaufman } \text { et al., } 1997\end{array}$ \\
\hline Nairobi & $0.36(0.036)$ & $0.38(0.032)$ & 0.33 \\
Mbita & $0.34(0.037)$ & $0.34(0.029)$ & \\
Malindi & $0.38(0.035)$ & $0.35(0.023)$ & \\
Mount Kilimanjaro & $0.40(0.038)$ & $0.35(0.038)$ & \\
\hline
\end{tabular}

\section{Aerosol Optical Depth Retrieval and validation}

We note the variation in the Vis/SWIR ratios used in the hypothetical model and those derived for AOD retrieval. This variation leads to either an overestimation or underestimation of surface reflectance, hence impacting negatively on aerosol reflectance that is necessary for accurate AOD retrieval over the region. Thus to increase the level of confidence in the derived aerosol products, a comprehensive validation process of the retrieved AOD must be effected. Here, the retrieved AOD at $550 \mathrm{~nm}$ wavelength from Level-3 MODIS gridded atmosphere monthly global product and that derived from the developed algorithm was implemented via AERONET AOD (Level 1.5-cloud screened) but limited to within \pm 30 minutes of MODIS Terra overpass time. Correlation between (MODIS, developed algorithm) and AERONET retrieved AOD in each season and study site for the stated period except Mount Kilimanjaro are shown in Figure 5. 

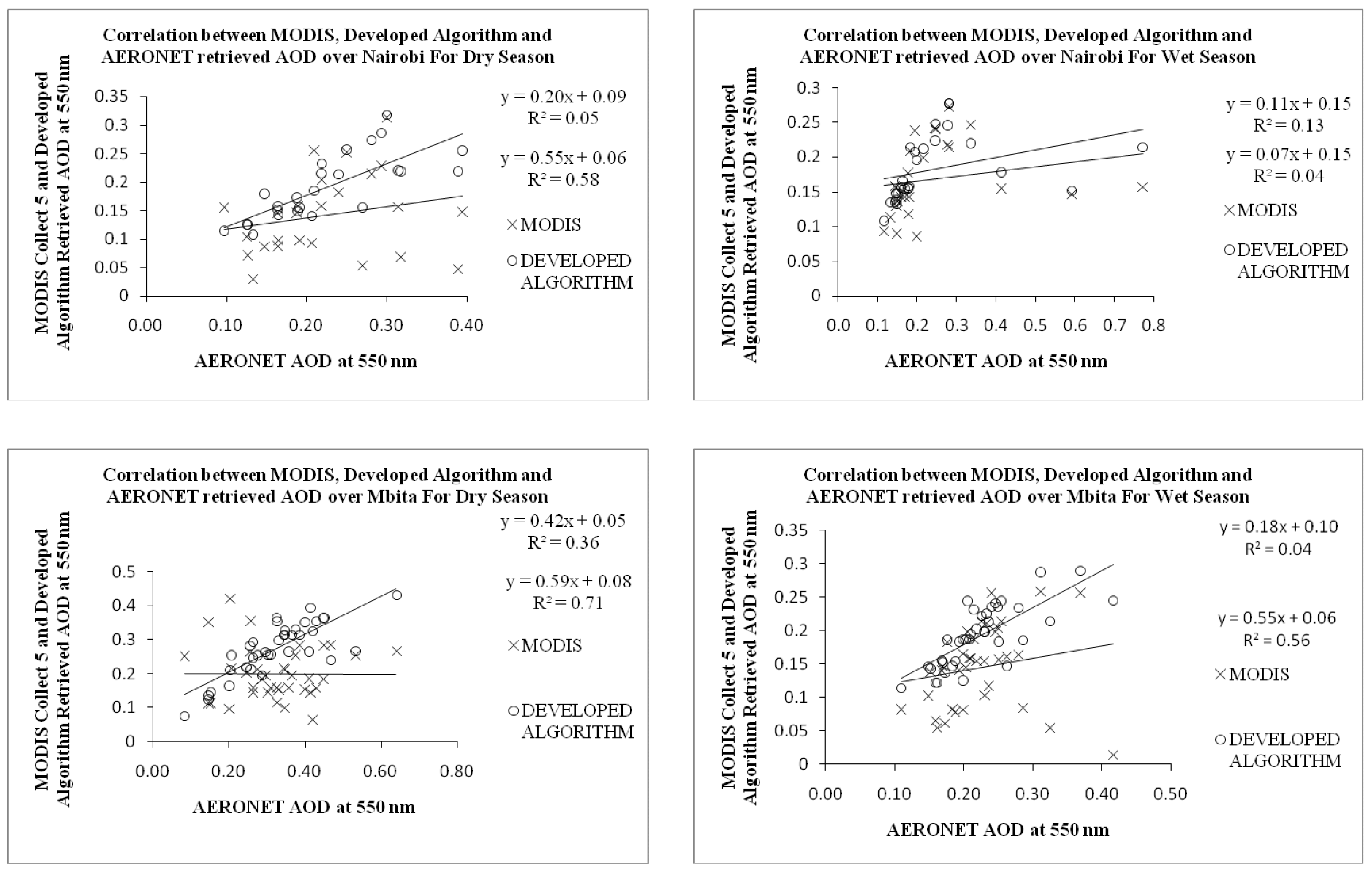

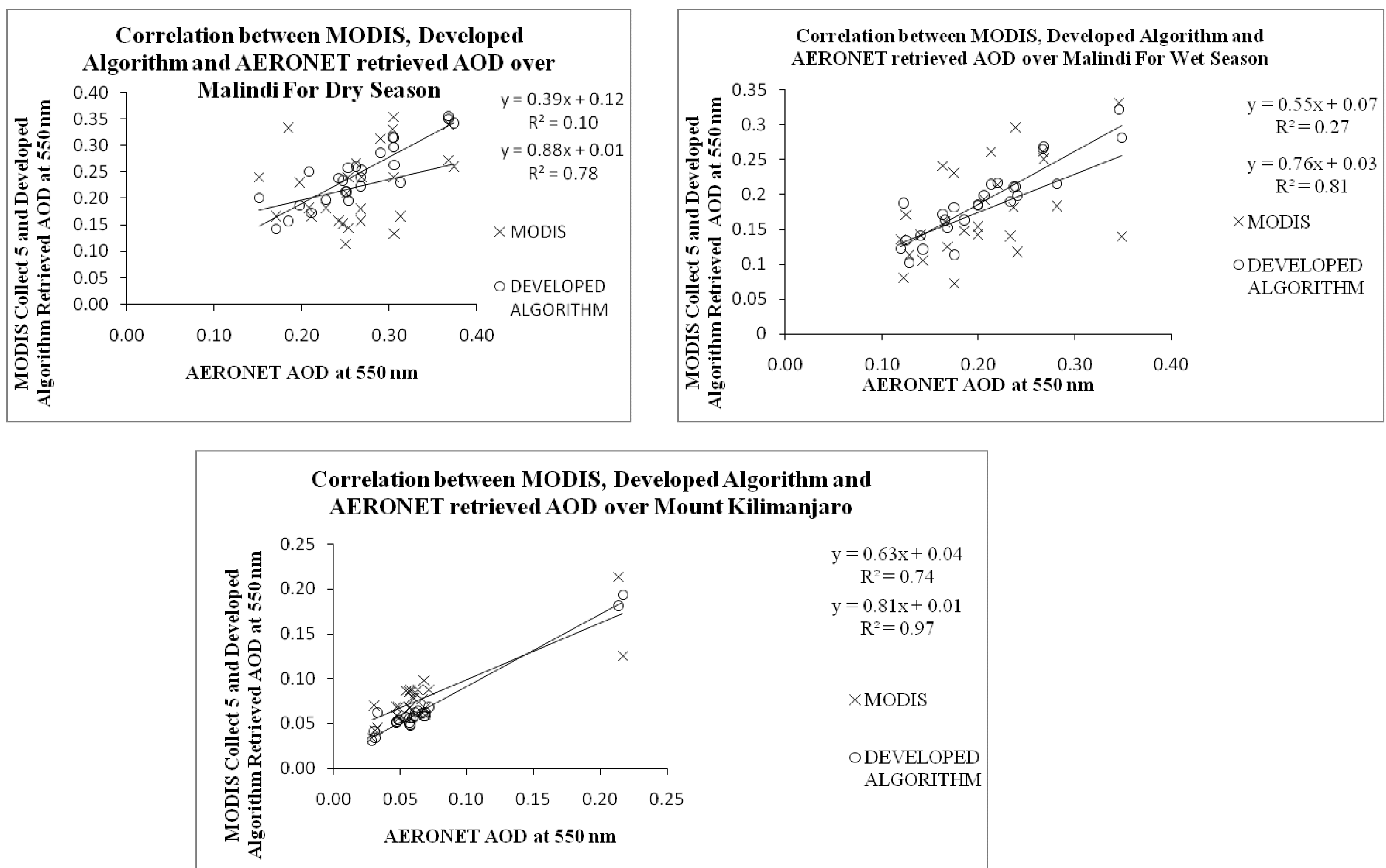

Figure 5: Correlations between (MODIS, developed algorithm) and AERONET retrieved AOD for dry season (Column 1) and wet season (Column 2) except Mount Kilimanjaro 
Correlations between the derived AOD from MODIS Terra collection 5, developed algorithm and AERONET in each season are presented in Figure 5. The correlation coefficients between retrieved AOD for developed algorithm and AERONET were higher as compared to that of MODIS collection 5 and AERONET over each study site and season. This was attributed to improper assumptions of surface reflectance and selection of aerosol type
(Jethva et al., 2005; 2010, Tripathi et al., 2005, More et al., 2013) that were addressed by the developed algorithm. Details of the correlation coefficients between (MODIS, developed algorithm) and AERONET retrieved AOD for each season except Mount Kilimanjaro as a result of luck of AERONET data over any of the three AERONET site during the dry season are shown in Table 2.

Table 2: Regression coefficients between (MODIS, developed algorithm) and AERONET retrieved AOD for each season except Mount Kilimanjaro

\begin{tabular}{llllll}
\hline Site of Study & \multicolumn{2}{l}{ Dry Season } & \multicolumn{3}{l}{ Wet Season } \\
\cline { 2 - 6 } & $\begin{array}{l}\text { MODIS verses } \\
\text { AERONET }\end{array}$ & $\begin{array}{l}\text { Developed } \\
\text { verses AERONET }\end{array}$ & $\begin{array}{l}\text { MODIS verses } \\
\text { AERONET }\end{array}$ & $\begin{array}{l}\text { Developed Algorithm } \\
\text { verses AERONET }\end{array}$ \\
\hline Nairobi & 0.05 & 0.58 & 0.04 & 0.13 \\
Mbita & 0.36 & 0.71 & 0.04 & 0.56 \\
Malindi & 0.10 & 0.78 & 0.27 & 0.81 \\
\hline Mount & Kilimanjaro & & & & \\
\hline
\end{tabular}

At low AERONET AOD values, the two algorithms i.e. MODIS and developed agree over each study and season but as the AERONET AOD value increases, a discrepancy is noted between the two. This discrepancy is associated to the use of NDVI (MODIS algorithm) and AFRI (developed algorithm). Normally, the use of NDVI which cannot exactly represent an accurate vegetation state for estimation of surface characteristics particularly under strong aerosol influence explains the low MODIS verse AERONET retrieved AOD correlation (Lee et al., 2006). Alternatively, AFRI is not always affected by aerosol presence and it also assesses the sensitivity of surface reflectance to aerosol retrieval (Lee et al., 2006, Karnieli et al., 2001). Hence, the results that indicate high regression coefficients to that of AERONET over each study site and season. This therefore emphasizes the need of using AFRI instead of NDVI in the aerosol retrieval algorithm of AOD over the region of interest since the previous is based on the ability of SWIR bands to penetrate the atmospheric column even when aerosols such as smoke or sulfates exist. Consequently, AFRI has a major application in assessing vegetation in the presence of smoke anthropogenic pollution and volcanic plumes (Karnieli et al., 2001). High regression coefficients presented by the developed algorithm as compared to MODIS collection 5 implies that more retrieved AOD from the previous algorithm is more comparable to AERONET retrieved AOD.

\section{Conclusion}

A new developed algorithm forAOD retrieval utilizing MODIS L1B calibrated reflectance data at a resolution of $500 \mathrm{mis}$ described, tested and validated using AERONET AOD between 2000-2013 depending on the site of study. The developed algorithm uses MRT coupled with AFRI instead of NDVI in the AOD 
retrieval over various land surfaces in the region. The Vis/SWIR ratio differs from the one proposed for AOD retrieval in the hypothetical model, this implies that the hypothetical model cannot always be used to accurately calculate surface reflectance for aerosol retrieval over East Africa. Results indicate that retrieved AOD from the developed algorithm are more consistent with that of AERONET over each study site and season as compared to that of MODIS collection 5. This then emphasizes the need of using AFRI plus accurate selection of surface characteristics and aerosol type for accurate AOD retrieval over East Africa, hence increasing the confidence in exploiting remotely sensed data over the region.

\section{Acknowledgement}

This work wassupported by the National Council for Science and Technology Grant funded by the Government of Kenya (NCST/ST\&I/RCD/4 ${ }^{\mathrm{TH}}$ call $\mathrm{PhD} / 201$ ).The authors wish to thank the NASA Goddard Earth Science Distributed Active Archive for MODIS Level $1 \mathrm{~B}$ and level 3 data. Brent Holben and the group are acknowledged for installing, maintaining and allowing the use of the optical data derived from AERONET sun photometers.

\section{References}

Ackerman, S.A., Strabala, K., Menzel, P., Frey, R., Moeller, C., Gumley, L., Baum, B., Seeman, S.W. and Zhang, H. (1998). Discriminating clearskyfrom cloud with MODIS. Algorithm theoretical basis document (MOD35). J. Geophys. Res., 103: 32141-32157.

Bucholtz, A. (1995). Rayleigh-scattering calculations for the terrestrialatmosphere. Appl. Opt., 34: 2765-2773.
Chu, A., Kaufman, Y.J., Ichoku, C., Remer, L.A., Tanré, D. and Holben, B.N. (2002). Validation of MODIS aerosol optical depth retrieval over land.Geophys. Res. Lett., 29(12): 14.

D'Almeida, G.A., (1986). A model for Saharan dust transport, J. Clin. Appl. Meteorol., 24: 903-916.

De Graaf, M., Tilstra, L.G., Aben, I. and Stammes, P. (2010). Satellite observations of the seasonal cycles of absorbing aerosols in Africa related to the monsoon rainfall, 1995-2008, Atmos. Environ., 44:1274-1284.

Engelstaedter, S., Tegen, I., and Washington, R. (2006). North African dust emissions and transport. Earth Sci. Rev., 79(1-2): 73-100.

Fairman, J.G., Nair, U.S., Christopher, S.A. and Mölg, T. (2011). Land use change impacts on regional climate over Kilimanjaro. J. Geophys. Res.,116:(D03110) Doi: 10.1029/2010JD014712.

Geogdzhayev, I.V., Mishchenko, M.I., Rossow, W.B., Cairns, B. and Lacis, A.A. (2002). Global two-channels AVHRR retrievals of aerosol properties over oceans for the period of NOAA-9 observations and preliminary retrievals using NOAA-7 and NOAA-11 data, J. Atmos. Sci., 59:262-278.

Gillingham, S.S., Flood, N., Gill, T.K. and Mitchell, R.M. (2012). Limitations of the dense dark vegetation method for aerosol retrieval under Australian conditions. Remote Sensing Letters, 31: 67-76.

Guo, J., Xiao, H., Xue, Y., Che, H., Xiaoye, Z., Cao, C., Jie, G. and Hao, Z. (2009). A new method to retrieve aerosol optical thickness from satellite images on a parallel system, Particuology, 7: 392-398. 
Holben, B.N., Eck, T.F., Slutsker, I., Tanre, D., Buis, J.P., Setzer, A., Vermote, E., Reagan, J.A., Kaufman, Y.J., Nakajima, T., Lavenu, F., Jankowiak, I. and Smirnov, A. (1998). AERONET-A federated instrument network and data archive for aerosol characterization, Remote Sens. Environ. 66:1-16.

Höller, R., Nagl, C., Haubold, H., Fanton D'Andon, O. and Garnesson, P. (2005). Evaluation of MERIS aerosol products for national and regional air quality in Austria. ESA Proceedings, MERIS/(A) ATSR Workshop, ESRIN, Frascati, Italy.

Hsu, N.C., Tsay, S.C., King, M.D. and Herman, J.R. (2004). Aerosol properties over bright-reflecting source regions, IEEE Trans. Geosci. Remote Sens., 42(3): 557-569.

Hsu, M.S. and Burke, H.K. (2003). Multisensor fussion with hyperspectral imaging data: Detection and classification, Lincoln Laboratory Journal, 14:145-159.

Hsu, N.C., Tsay, S.C., King, M.D. and Herman, J.R. (2006). Deep blue retrievals of Asian aerosol properties during ACE-Asia, IEEE Trans. Geosci. Remote Sens., 44(11): 31803195.

Intergovernmental Panel on Climate Change (IPCC) (2007). Climate change 2007: The physical science basis. Contribution of working group I to the fourth assessment report of the intergovernmental panel on climate change. In: Solomon, S., Qin, D., Manning, M., Chen, Z., Marquis, M., Averyt, K.B.,Tignor, M., and Miller, H.L. (eds), Cambridge University Press, Cambridge, UK and New York, USA.

Jethva, H., Satheesh, S.K. and Srinivasan, J. (2005). Seasonal Variabilities over the Indo-Gangatic Basin. J. Geophys. Res., 110: (D21204), Doi: 10.1029/2005JD005938.

Jethva, H., Satheesh, S.K., Shrinivasan, J. and Levy, R.C. (2010). Improved Retrievals of Aerosol Size-Resolved Properties from Moderate Resolution Imaging Spectroradiometer over India: Role of Aerosol Model and Surface Reflectance. J. Geophys. Res. 115: D18213, Doi: 10.1029/2009JD013218.

Kaufman, Y.J., Tanré, D., Gordon, H.R., Nakajima, T., Lenoble, J., Frouin, R., Grassl, H., Herman, B.M., King, M.D. and Teillet, P.M. (1997). Passiveremote sensing of tropospheric aerosol and atmospheric correction for the aerosol effect, $J$. Geophys. Res., 102(D14): 1681516830.

Kaufman, Y.J. and Tanre, D. (1998). Algorithm for Remote Sensing of Tropospheric Aerosol from MODIS, 1998. NASA MOD04 product ATBDreport.

Kaufman, Y.J., Koren, I., Remer, L.A., Tanré, D., Ginoux, P. and Fan, S. (2005). Dust trans- port and deposition observed from the TerraModerate Resolution Imaging Spectroradiometer (MODIS) spacecraft over the Atlantic Ocean. $J$. Geophys. Res. 110, (D10S12).Doi: 10.1029/2003JD004436.

Karnieli, A., Kaufman, Y.J., Remer, L.A. and Ward, A. (2001). AFRI-Aerosol free vegetation index. Remote Sens. Environ., 77: 10-21.

Lee, K.H., Kim, Y.J., von HoyningenHuene, W. and Burrow, J.P. (2006). Influence of land surfaceeffects on MODIS aerosol retrieval usingthe BAER method over Korea. Int. J. Remote Sens., 27: 2813-2830. 
Retrieval of Aerosol Optical Depth over Ecologically Stressed East African.................МКОКHA et al.

Levy, R.C., Remer, L.A., Martins, J.V., Kaufman, Y.J., Plana-fattori, A., Redemann, J. and Wenny, B. (2004). Evaluation of the MODIS aerosol retrievals over ocean and land during CLAMS, J. Atmos. Sci., 62(4):974992.

Levy, R.C., Remer, L.A., Mattoo, S., Vermote, E.F. and Kaufman, Y.J. (2007). Second-generation operational algorithm: retrieval of aerosol properties over land from inversion of moderate resolution imaging Spectroradiometer spectral reflectance. J. Geophys. Res. 112, (D13211). Doi: 10.1029/2006JD007811.

Makokha, J.W. and Angeyo, H.K. (2013). Investigation of Radiative Characteristics of the Kenyan Atmosphere due to Aerosols Using Sun Spectrophotometry Measurements and the COART Model, Aerosol and Air Quality Research., 13:201-208.

More, S., Pradeep Kumar, P., Pawan, G., Devara, P.C.S. and Aher, G.R. (2013). Comparison of aerosol Products Retrieved from AERONET, MICROTOPS and MODIS over a Tropical Urban city, Pune, India, Aerosol and Air Quality Research,13: 107-121.

Prospero, J.M., Barrett, K., Church, T., Dentener, F., Duce, R.A., Galloway, H., Levy II, H., Moody, J. and Quinn, P. (1996). Atmospheric deposition of nutrients to the North Atlantic basin. Biogeochemistry 35: 27-73.

Prospero, J., Ginoux, P., Torres, O. and Nicholson, S.E. (2002). Environmental Characterization of Global sources of atmospheric soil dust derived from the NIMBUS-7 TOMS absorbing aerosol product,
Rev. Geophys., 40(1), 1002, doi: 10.1029/20000GR000095.

Reid, J.S., Kinney, J.E., Westphal, D.L., Holben, B.N., Ellsworth, J.W., SiChee, T., Danniel, P.E., Campell, J.R., Sandar, A.C., Colarco, P.R., Haflidi, H.J., John, M.L., Hal, B.M., Michael, M.L., Peter, P., Joseph, M.P., Elizabeth, A.R., Lorraine, A.R., Russell, P.B., Dennis, L.S., Alexander, S. and Didier, T. (2003). Analysis of measurements of Saharan dust by airborne and ground-based remote sensing methods during the Puerto Rico Dust Experiment (PRIDE). J. Geophys. Res. 108 (D19). Doi: 10.1029/2002JD002493.

Reid, J.S., Koppmann, R., Eck, T.F. and Eleuterio, D.P. (2005). A review of biomass burningemissions part II: intensive physical properties of biomass burning particles. Atmos. Chem. Phys. 5:799-825. doi:10.5194/acp-5-799-2005

Remer, L.A., Kaufman, Y.J., Tanré, D., Mattoo, S., Chu, D.A., Martins, J.V., Li, R.R., Ichoku, C., Levy, R.C., Kleidman, R.G., Eck, T.F., Vermote, E. and Holben, B.N. (2005). The MODIS aerosol algorithm, products, and validation, J. Atmos. Sci., 62(4): 947-973.

Salomonson, V.V., Barnes, W.L., Maymon, P.W., Montgomery, H.E. and Ostrow, H. (1989). "MODIS: Advanced Facility Instrument for Studies of the Earth as a System." IEEE Trans. Geosci. Remote Sensing., 27: 145-153.

Seery, B.D., Cramer, D.B., Stevens, C and Lencioni, D. (1996). EO1: NASA's First New Millennium Earth Orbiting Mission,"SPIE, 2810, 4-10.

Shaw, G.A and Burke, H.K. (2003). Spectral imaging for remote sensing. Lincoln Laboratory Journal, 14:3-28. 
Torres, O., Bhartia, P. K., Herman, J. R., Ahmed, Z. and Gleason, J. (1998). Derivationof aerosol properties from satellite measurements of backscatteredultraviolet radiation: Theoretical basis, J. Geophys. Res., 103: $17,099-17,110$

Torres, O., Bhartia, P. K., Herman, J. R., Sinyuk, A., Ginoux, P. andHolben, B. (2002). A long-term record of aerosol optical depth from TOMSobservations and comparisons to AERONET measurements, $J$. Atmos. Sci., 59: 398- 413.

Tripathi, S.N., Dey, S., Chandel, A., Srivastava, S., Singh, R.P. and Holben, B.N. (2005). Comparison of MODIS and AERONET Derived Aerosol Optical Depth overGanga Basin, India. Ann. Geophys., 23: 1093-1101.

Vermote, E.F., Tanre, D., Deuze, J.L., Morcrette, J.J., Herman, M. and Kotchenova, S.Y (2006). "Second simulation of the satellite signal in the solar spectrum-vector: User Guide manual," University of Maryland/Laboratoired'OptiqueAtm ospherique.
Von Hoyningen-Huene, W., Freitag, M., and Burrows, J.B. (2003). Retrieval ofaerosol optical thickness over land surfaces from top-of-atmosphere radiance. J. Geophys. Res. 108(D9): 4260. Doi: 10.1029/2001JD002018.

Von Hoyningen-Huene, W., Kokhanovsk, A.A., Wuttke, A.A., Buchwitz, M., Noël, S., Gerilowski, K., Burrows, J.B., Latter, B., Siddans, R. and Kerridge, B.J. (2007). Validation of SCIAMACHY top-of-atmosphere reflectance for aerosol remote sensing using MERIS L1 data, Atmos. Chem. Phys., 7: 97-106.

Wittrock, F., Oetjen, H., Richter, A., Fietkau, S., Medeke, T., Rozanov, A. and Burows, J.P. (2004). MAXDOAS measurements of atmospheric trace gases in Ny-Álesund-Radiative transfer studies and their application, Atmos. Chem. Phys., 4: 955-966.

Wong, M. S., Lee, K. H., Nichol, E.J. and Li, Z. (2010). Retrieval of Aerosol Optical Thickness using MODIS $500 \times 500 \mathrm{~m}^{2}$, a study in Hong Kong and the Pearl River Delta region, IEEE Trans. Geosci. Remote Sens., 48(8): 3318-3327. 